УДК 349.22

DOI https://doi.org/10.32782/2409-4544/2020-1/15

I. Якушев

\title{
Трудовий договір як підстава виникнення трудових правовідносин
}

Стаття присвячена аналізу трудового договору як форми реалізації права на працю і підстави (юридичного факту) виникнення трудових правовідносин. Під трудовим договором варто розуміти дії працівника i роботодавця, спрямовані на набуття трудових прав та обов'язків. Наслідком передбачених законодавством дій працівника і роботодавця $є$ виникнення трудових правовідносин. Особливості виконання трудової функції працівником у трудових правовідносинах обумовлюють диференціацію дій суб'єктів, необхідних для виникнення трудових правовідносин. В одних випадках для виникнення трудових правовідносин достатньо спільного волевиявлення працівника i роботодавця, а в інших - передбачається спеціальна процедура (конкурс, вибори, погодження, рекомендація тощо).На підставі аналізу норм Кодексу законів про працю України зроблено висновок про необхідність розмежування укладення трудового договору та його оформлення. Укладення трудового договору може відбуватися в результаті досягнення згоди про виконання роботи або фактичного допуску працівника до роботи, а може передбачатися наявність юридичного складу (наприклад, конкурсний відбір, обрання на посаду та т. п.). Оформлення трудового договору відбувається шляхом видання наказу чи розпорядження про прийняття на роботу або призначення на посаду. Обгрунтовано висновок про те, що підставою виникнення трудових правовідносин $є$ трудовий договір, незалежно від його форми (письмової або усної) і виду (контракт, трудовий договір про роботу за сумісництвом, трудовий договір про виконання тимчасових чи сезонних робіт). Одним 3 обов'язкових умов трудового договору, без якого цей договір не може вважатися укладеним, $є$ вказівка про трудові функції працівника відповідно до Класифікатора професій. Оформлення трудового договору відбувається шляхом видання наказу, в якому вказується посада, на яку призначається працівник, або робота, яку він виконуватиме.

Ключові слова: право на працю, трудовий договір, трудові правовідносини.

Постановка наукової проблеми та її значення. Праця є природною здатністю людини i необхідною умовою іiі життя. Завдяки праці людина створює матеріальні цінності, що забезпечують належне існування для неї та іiі родини. Стаття 43 Конституції України закріплює право на працю кожного, «що включає можливість заробляти собі на життя працею, яку він вільно обирає або на яку вільно погоджується. Держава створює умови для повного здійснення громадянами права на працю, гарантує рівні можливості у виборі професії та роду трудової діяльності» [1].

Володіння та використання здатності до праці є природним і невід'ємним правом кожної людини. Реалізація цього права відбувається різними способами, які мають свою особливу правову форму та характеризують особу як зайняту. Закон України «Про зайнятість населення» у п. 7 ч. 1 ст. 1 зазначає, що зайнятість - це «не заборонена законодавством діяльність осіб, пов'язана із задоволенням їх особистих та суспільних потреб з метою одержання доходу (заробітної плати) у грошовій або іншій формі, а також діяльність членів однієї сім'ї, які здійснюють господарську діяльність або працюють у суб'єктів господарювання, заснованих на їх власності, у тому числі безоплатно» [2].

На сьогодні можна виділити такі основні шляхи реалізації громадянами права на працю: вступ у трудові правовідносини; виконання роботи за цивільно-правовими договорами; зайняття підприємницькою діяльністю; самозайнятість тощо. Проте, найбільш поширеною формою зайнятості населення залишається наймана праця, тобто реалізація права на працю відбувається шляхом вступу особи у трудові правовідносини.

Зміни у законодавстві щодо порядку допуску працівника до роботи та вилучення норми про презумпцію укладення трудового договору у зв'язку з фактичним допуском працівника до роботи, заміщення вакантних посад за конкурсом, відсутність у спеціальних законах норм про укладення трудового договору вимагають з'ясування сутності трудового договору як юридичного факту i підстави виникнення трудових правовідносин, що і обумовлює актуальність дослідження.

() Якушев I., 2020 
Аналіз досліджень цієї проблеми. Питання реалізації права на працю шляхом укладення трудового договору було предметом дослідження багатьох відомих вчених. Розглядаючи підстави виникнення трудових правовідносин, аналізуючи зміст нормативних актів щодо процедури укладення трудового договору та оформлення трудових правовідносин, висновки вчених не завжди співпадають, а в окремих випадках містять суперечності, на які і буде звернуто увагу.

Формулювання мети та завдань статті. Метою статті є обгрунтування трудового договору як єдиної підстави виникнення трудових правовідносин. Для досягнення цієї мети ставиться завдання 3'ясувати значення трудового договору як юридичного факту, розкрити його фактичний і юридичний склад, розмежувати порядок укладення від оформлення трудового договору.

Виклад основного матеріалу й обгрунтування отриманих результатів дослідження. Чинний Кодекс законів про працю України (далі - КЗПП) у ч. 2 ст. 2 передбачає: «Працівники реалізують право на працю шляхом укладення трудового договору про роботу на підприємстві, в установі, організації або з фізичною особою» [3]. Отже, трудові правовідносини виникають у результаті укладення між роботодавцем і працівником трудового договору з приводу застосування праці та іiі оплати $[4$, с. 16]. Законодавство визнає трудовий договір підставою виникнення трудових правовідносин, а отже і юридичним фактом, з яким пов'язано їх виникнення.

На думку В. В. Жернакова, у ряді випадків для виникнення трудових правовідносин 3 окремими категоріями працівників потрібний юридичний (фактичний) склад із декількох актів. Юридичними елементами фактичних складів, поряд із трудовим договором, на його думку, можуть виступати такі юридичні акти: акт обрання на виборну посаду; акт призначення на посаду; акт вступу в члени кооперативу (чи товариства, де особиста праця є обов'язковою умовою членства); акт направлення на роботу при працевлаштуванні молодих фахівців, підготовка яких здійснювалася за державним замовлення; рішення суду про працевлаштування при необгрунтованій відмові у прийнятті на роботу тощо [5, с. 22-23].

Подібної точки зору дотримується В. А. Андронова, яка вважає, що у випадках, передбачених законодавством, статутними документами, трудові правовідносини виникають на підставі трудового договору в результаті: призначення на посаду; обрання на посаду; обрання за конкурсом на заміщення відповідної посади; направлення на роботу уповноваженим відповідно закону органом у рахунок встановленої законом квоти; судового рішення про укладення трудового договору; направлення для проходження альтернативної (невійськової) служби [6, с. 16].

П. Д. Пилипенко вказує, що КЗпП передбачає фактично дві підстави виникнення трудових правовідносин: трудовий договір та контракт. Разом із цим, вчений зазначає й інші підстави, а саме: призначення державного службовця на посаду; обрання на виборну посаду; обрання за конкурсом; направлення на роботу молодих фахівців; судове рішення про укладення трудового договору [7, с. 30$124,133,134]$.

В. В. Срьоменко до підстав виникнення трудових правовідносин відносить: укладення трудового договору (контракту); обрання на посаду; обрання за конкурсом; призначення на посаду; прийняття на роботу молодих фахівців; направлення на роботу в рахунок броні (квоти); прийом (вступ) у члени, якщо членство обумовлено обов'язковістю особистої праці [8, с. 68-78, 170].

К. Ю. Мельник підставами виникнення трудових правовідносин, крім трудових договорів, вважає акти призначення на посаду, обрання на посаду, затвердження на посаді, результат конкурсу, рішення суду, направлення державною службою зайнятості на роботу за рахунок встановленої квоти $[9$, c. 233].

Незважаючи на відмінності у твердженнях, спільним для всіх вчених є визнання трудового договору підставою виникнення трудових правовідносин. Згідно ч. 1 ст. 21 КЗпП, «Трудовий договір $€$ угода між працівником і власником підприємства, установи, організації або уповноваженим ним органом чи фізичною особою, за якою працівник зобов'язується виконувати роботу, визначену цією угодою, з підляганням внутрішньому трудовому розпорядкові, а власник підприємства, установи, організації або уповноважений ним орган чи фізична особа зобов'язується виплачувати працівникові заробітну плату і забезпечувати умови праці, необхідні для виконання роботи, передбачені законодавством про працю, колективним договором і угодою сторін».

Термін «угода» вживався у Цивільному кодексі Української РСР, під яким визнавалися «дії громадян і організацій, спрямовані на встановлення, зміну або припинення цивільних прав або обов'язків» [10]. У чинному Цивільному кодексі України цей термін замінено на «правочин», під яким розуміють дію особи, спрямовану на набуття, зміну або припинення цивільних прав та обов'язків [11]. Як бачимо, за змістом наведені визначення є тотожними. 
Враховуючи норми цивільного законодавства під трудовим договором варто розуміти дії працівника i роботодавця, спрямовані на набуття трудових прав та обов'язків. Наслідком передбачених законодавством дій працівника і роботодавця є виникнення трудових правовідносин.

Особливості виконання трудової функції працівником у трудових правовідносинах обумовлюють диференціацію дій суб’єктів, необхідних для виникнення трудових правовідносин. В одних випадках для виникнення трудових правовідносин достатньо спільного волевиявлення працівника і роботодавця, а в інших - передбачається спеціальна процедура (конкурс, вибори, погодження, рекомендація тощо). Власне, необхідність вчинення комплексу дій для виникнення трудових правовідносин, зумовила відмінності наукових тверджень щодо підстав виникнення трудових правовідносин.

Аналіз висловлених вченими міркувань щодо підстав виникнення трудових правовідносин дозволяють виділити такі основні точки зору: одні вважають підставою лише трудовий договір (наприклад, В. В. Жернаков, В. А. Андронова), інші, зазначаючи, що підставою виникнення трудових правовідносин є трудовий договір, допускають також інші підстави: призначення державного службовця на посаду; обрання на виборну посаду; обрання за конкурсом; направлення на роботу молодих фахівців; судове рішення про укладення трудового договору (наприклад, П. Д. Пилипенко), треті вважають що підставами виникнення трудових правовідносин можуть бути різні обставини, зокрема: укладення трудового договору (контракту), обрання на посаду, обрання за конкурсом, призначення на посаду, затвердження на посаді, прийняття на роботу молодих фахівців, направлення на роботу в рахунок броні (квоти), прийом (вступ) у члени, якщо членство обумовлено обов'язковістю особистої праці, рішення суду, направлення державною службою зайнятості на роботу за рахунок встановленої квоти (наприклад, В. В. Срьоменко, К. Ю. Мельник).

На нашу думку, переважна більшість зазначених випадків не є самостійними підставами виникнення трудових правовідносин а стосуються процедури укладення трудового договору, який $\mathrm{i}$ буде підставою їх виникнення. Наприклад, абзац 1 ч. 11. ст. 55 Закону України «Про вищу освіту» передбачає, що під час заміщення вакантних посад науково-педагогічних працівників укладенню трудового договору (контракту) передує конкурсний відбір, а ч. 1 ст. 43 вказаного закону закріплює, що керівник закладу вищої освіти за згодою більшості від повного складу органу громадського самоврядування факультету (навчально-наукового інституту) закладу вищої освіти призначає керівника факультету (навчально-наукового інституту) на строк до п’яти років та укладає 3 ним контракт [12].

У зв’язку зі змінами у законодавстві ряд обставини втратили свою актуальність. Наприклад, направлення на роботу молодих фахівців та направлення на роботу в рахунок броні (квоти) були передбачені законодавством, що втратило чинність. При цьому, підставою виникнення трудових правовідносини був трудовий договір, укладенню якого передувало направлення на роботу. Нині Закон України «Про зайнятість населення» у ч. 10 ст. 1 дає визначення: «молодий працівник громадянин України віком до 35 років, випускник закладу професійної (професійно-технічної), фахової передвищої або вищої освіти, який у шестимісячний строк після закінчення навчання працевлаштувався самостійно або за направленням закладу освіти чи територіального органу центрального органу виконавчої влади, що реалізує державну політику у сфері зайнятості населення та трудової міграції, та продовжує працювати протягом трьох років за кваліфікацією, яку він набув під час навчання, в тому числі незалежно від місця першого працевлаштування» [2].

Відповідно до чинного законодавства роботодавець зобов'язаний укласти трудовий з: особою, запрошеною на роботу в порядку переведення 3 іншого підприємства, установи, організації за погодженням між керівниками підприємств, установ, організацій (ч. 4 ст. 24 КЗпП); вагітними жінками і жінками, які мають дітей віком до трьох років, а одинокими матерями - за наявністю дитини віком до чотирнадцяти років або дитини з інвалідністю (ч. 1 ст. 184 КЗПП); працівниками після закінчення їх повноважень за виборною посадою (ст. 118 КЗпП); працівником, у разі поворотного прийняття на роботу (ст. 421 КЗпП) та іншими. У випадку невиконання роботодавцем зазначеного обов'язку, працівник має право звернутися до суду, а суд, при обгрунтованості позову, зобов'язує роботодавця укласти трудовий договір [13]. Отже, підставою виникнення трудових правовідносин у даному випадку є не рішення суду, а трудовий договір, який зобов’язаний укласти роботодавець 3 працівником за рішенням суду.

Особливості вступу у трудові правовідносини суддів, прокурорів, державних службовців та інших осіб, наділених владними повноваження, передбачено Конституцією України та спеціальними законами. Так, ст. 128 Конституції України і ст. 80 Закону України «Про судоустрій і статус суддів» 
передбачають, що призначення на посаду судді здійснюється Президентом України за конкурсом [14].

У Законі України «Про прокуратуру» зазначено, що Генеральний прокурор призначає прокурорів на адміністративні посади та посади прокурорів Офісу Генерального прокурора (п.п. 3, 5 ч. 1 ст. 9), а керівник прокуратури за наслідками спеціальної перевірки, передбаченої антикорупційним законодавством, своїм наказом призначає кандидата на посаду прокурора не пізніше 30 днів 3 дня отримання подання відповідного органу, що здійснює дисциплінарне провадження (ч. 1 ст. 35). Відповідний орган, що здійснює дисциплінарне провадження, проводить конкурс на зайняття вакантних посад прокурора на підставі рейтингу кандидатів. За результатами конкурсу відповідний орган, що здійснює дисциплінарне провадження, надсилає керівникові відповідної прокуратури подання про призначення кандидата на посаду прокурора органу прокуратури, на зайняття вакантної посади в якому кандидат подавав заяву (ч. 4, 5 ст. 34 Закону України «Про прокуратуру») [15].

Стаття 21 Закону України «Про державну службу» передбачає, що вступ на державну службу здійснюється шляхом призначення громадянина України на посаду державної служби за результатами конкурсу (ч. 1). Особа, яка вступає на посаду державної служби вперше, набуває статусу державного службовця 3 дня публічного складення нею Присяги державного службовця, а особа, яка призначається на посаду державної служби повторно, - 3 дня призначення на посаду (ч. 3).

Наведені норми законодавства ще раз підтверджують, що для вступу у трудові правовідносини необхідним є вчинення суб’єктами певної послідовності дій, які в сукупності призведуть до виникнення цих правовідносин. Призначення на посаду є завершальним етапом цих дій та їх належним оформленням.

Процедура вчинення певних дій щодо укладення трудового договору у чинному КЗпП обмежується закріпленням вимог лише щодо форми трудового договору (ч. 1 ст. 24), обов'язку працівника подати документи, передбачені законодавством (ч. 2 ст. 24), забороною вимагати при укладенні трудового договору деякі відомості та документи (ст. 25). Оформляється укладення трудового договору наказом чи розпорядженням роботодавця, що прямо зазначено у ч. 3 ст. 24 КЗпП: «працівник не може бути допущений до роботи без укладення трудового договору, оформленого наказом чи розпорядженням власника або уповноваженого ним органу, та повідомлення центрального органу виконавчої влади 3 питань забезпечення формування та реалізації державної політики з адміністрування єдиного внеску на загальнообов'язкове державне соціальне страхування про прийняття працівника на роботу в порядку, встановленому Кабінетом Міністрів України».

Згідно Інструкції про порядок ведення трудових книжок записи про найменування роботи, професії або посади, на яку прийнятий працівник, виконуються відповідно до найменування професій і посад, зазначених у «Класифікаторі професій» (п. 2.14.), а згідно п. 2.4., усі записи в трудовій книжці про прийняття на роботу повинні точно відповідати тексту наказу (розпорядження) [16]. Отже, наказ (розпорядження) роботодавця повинен містити відомості про трудову функцію працівника шляхом вказівки про призначення на посаду. Призначення на посаду судді, прокурора, державного службовця $€$ фактично оформленням укладеного трудового договору, на підстав якого виникають трудові правовідносини.

Висновки. Враховуючи наведене вище, варто зауважити, що підставою виникнення трудових правовідносин є трудовий договір, незалежно від його форми (письмової чи усної) і виду (контракт, трудовий договір про роботу за сумісництвом, трудовий договір про виконання тимчасових чи сезонних робіт). Процедура укладення трудового договору може передбачати вчинення суб' єктами певних дій, які лише в сукупності призведуть до укладення трудового договору. Кожна окрема дія сама по собі не призводить до виникнення трудових правовідносин.

Однією 3 обов'язкових умов трудового договору, без якої трудовий договір не може вважатися укладеним, є вказівка про трудову функцію працівника відповідно до Класифікатора професій. Оформлення трудового договору відбувається шляхом видачі наказу, у якому зазначається посада, на яку призначається працівник, або робота, яку він буде виконувати.

\section{Джерела та література}

1. Конституція України: закон від 28.06.1996 р. № 254к/96-ВР // Відом. Верхов. Ради України. - 1996. - № 30. - Ст. 141 (із змінами).

2. Про зайнятість населення: Закон України від 05.07.2012 p. № 5067-VI. // Відом. Верхов. Ради України. - 2013. - № 24. - Ст. 243 (із змінами). 
3. Кодекс законів про працю України: затв. Законом Верховної Ради Української РСР від 10.12.1971 р. № 322-VIII. // Відом. Верхов. Ради Української РСР. - 1971. - Додаток до № 50. - Ст. 375 (із змінами). 4. Трудове право України. Академічний курс / П. Д. Пилипенко, В. Я. Бурак, З. Я. Козак та ін. За ред. П. Д. Пилипенка. - Київ: Концерн «Видавничий дім «Ін Юре», 2010. - 536 с.

5. Трудове право: підручник / В. В. Жернаков, С. М. Прилипко, О. М. Ярошенко та ін. За ред. В. В. Жернакова. - Харків: Право, 2012. - 496 с.

6. Андронова В. А. Юридичні факти у трудовому праві України: автореф. дис. ... канд.. юрид. наук: спец. 12.00.05 / В. А. Андронова. - Одеса, 2014. - 20 с.

7. Пилипенко П. Д. Підстави виникнення індивідуальних трудових правовідносин / П. Д. Пилипенко. - Київ: Знання, 2003. - 146 с.

8. Єрьоменко В. В. Підстави виникнення трудових правовідносин: дис. ... канд. юрид. наук : 12.00 .05 / В. В. Срьоменко; Національна юридична академія України ім. Я. Мудрого. - Харків. 1998. - 195 с.

9. Мельник К. Ю. Проблеми правового регулювання трудових відносин службовців правоохоронних органів: монографія. - Харків: Харківськ. нац. ун-т внутр, справ, 2009. - 360 с.

10. Цивільний кодекс Української РСР: кодекс від 18.07.1963 р. № 1540-VI [Електронний ресурс]. Режим доступу:https://zakon.rada.gov.ua/laws/show/1540-06.

11. Цивільний кодекс України: кодекс від 16.01.2003 р. № 435-IV [Електронний ресурс]. - Режим доступу: https://zakon.rada.gov.ua/laws/show/435-15 .

12. Про вищу освіту: Закон України від 01.07.2014 р. № 1556-VII [Електронний ресурс]. - Режим доступу: https://zakon.rada.gov.ua/laws/show/1556-18.

13. Про практику розгляду судами трудових спорів: постанова Пленуму Верховного Суду України від 06.11 .1992 p. № 9 [Електронний pecypc]. - Режим доступу: https://zakon.rada.gov.ua/ laws/show/v0009700-92.

14. Про судоустрій і статус суддів: Закон України від 02.06.2016 р. № 1402-VIII [Електронний ресурс]. - Режим доступу: https://zakon.rada.gov.ua/laws/show/1402-19.

15. Про прокуратуру: Закон України від 14.10.2014 р. № 1697VII [Електронний ресурс]. - Режим доступу: https://zakon.rada.gov.ua/laws/show/1697-18.

16. Інструкції про порядок ведення трудових книжок. Затверджено наказом Міністерства праці України, Міністерства юстиції України, Міністерства соціального захисту населення України 20.07.1993 p. № 58 [Електронний ресурс]. - Режим доступу: https://zakon.rada.gov.ua/laws/show /z011093.

Якушев И. Трудовой договор как основание возникновения трудовых правоотношений. Статья посвящена анализу трудового договора как формы реализации права на труд и основания (юридического факта) возникновения трудовых правоотношений. Под трудовым договором следует понимать действия работника и работодателя, направленные на возникновение трудовых прав и обязанностей. Вследствии предусмотренных законодательством действий работника и работодателя образуются трудовые правоотношения. Особенности выполнения трудовой функции работником в трудовых правоотношениях обусловливают дифференциацию действий субъектов, необходимых для возникновения трудовых правоотношений. В одних случаях для возникновения трудовых правоотношений достаточно общего волеизъявления работника и работодателя, а в других предусматривается специальная процедура (конкурс, выборы, согласования, рекомендация и т.д.). На основании анализа норм Кодекса законов о труде Украины сделан вывод о необходимости разграничения заключения трудового договора и его оформления. Заключение трудового договора может происходить в результате достижения согласия о выполнении работы или фактического допуска работника к работе, а может предусматриваться наличие юридического состава (например, конкурсный отбор, избрание на должность и т. п.). Оформление трудового договора происходит путем издания приказа или распоряжения о принятии на работу или назначения на должность. Обоснован вывод о том, что основанием возникновения трудовых правоотношений является трудовой договор, независимо от его формы (письменной или устной) и вида (контракт, трудовой договор о работе по совместительству, трудовой договор о выполнении временных или сезонных работ). Одним из обязательных условий трудового договора, без которого этот договор не может считаться заключенным, является указание о трудовой функции работника в соответствии с Классификатора профессий. Оформление трудового договора происходит путем издания приказа, в котором указывается должность, на которую назначается работник, или работа, которую он будет выполнять.

Ключевые слова: право на труд, трудовой договор, трудовые правоотношения. 
Yakushev I. Contract of Employment as a Basis for labor Legal Relations. The article deals with the analysis of the employment contract as a form of realization of the right to work and the legal fact of labor legal relations emergence. An employment contract is an actions taken by an employee and an employer aimed to acquireing of employment rights and responsibilities. The consequence of such actions of the employee and the employer, which are provided by the legislation, is emergence of labor legal relations. The peculiarities of the performance of the labor function by the employee in the employment relationship determine the differentiation of the actions of the subjects necessary for the emergence of the employment relationship. In some cases, for the emergence of the labor relationship is enough the common will of employee and the employer and in others - a special procedure (competition, election, approval, recommendation, etc.). Based on the analysis of the norms of the Labor Code of Ukraine, the author draws the conclusion about the need to distinguish between concluding the contract of employment and its execution. The conclusion of an employment contract may occur as a result of an agreement to perform some work, the actual admission of the employee to work, or it may imply the presence of the legal procedures (eg competitive selection, election for the position, etc.). The employment contract is executed by issuing an order or instruction on hiring or appointment to the position. The article substantiates that the basis of employment is an employment contract, regardless of its form (written or oral) and the type (contract, an employment contract for part-time work, an employment contract for temporary or seasonal work). One of the mandatory conditions of the contract of employment is an indication of the employee's job functions in accordance with the Classifier of Occupations. Without it the contract of employment cannot be considered as such that has been concluded. The employment contract is executed by issuing an order stating the position to which the employee is appointed or the work he will perform.

Key words: right to work, employment contract, labor relations. 